\title{
OPHIOGLOSSID FERNS IN MANITOBA: MOONWORTS, GRAPEFERNS AND NORTHERN ADDER'S-TONGUE
}

\author{
Richard J. Staniforth
}

336 Glenwood Crescent, Winnipeg, MB, R2L 1J9; Email:<richard_staniforth@yahoo.ca>

The Ophioglossaceae or adder's-tongue family is a small group of less than 100 species of ferns that are terrestrial or epiphytic and found worldwide. ${ }^{1}$ They are quite distinct morphologically from other ferns. Each plant has a single stem that is largely subterranean, and this supports a short-lived, usually single leaf that is composed of two parts: a sporophore that bears sporangia and a photosynthetic leaf blade or trophophore. ${ }^{1}$

This morphology contrasts with that of most other ferns, the leptosporangiate ferns, which produce their sporangia on the lower sides of their photosynthetic leaves. The relationship between the ophioglossid and leptosporangiate ferns has been a mystery for many years ${ }^{2,3}$; however, recent DNA research has suggested that the ophioglossids are more closely related to the tropical whisk fern family (Psilotaceae) than they are to the leptosporangiate ferns. ${ }^{1}$ Unfortunately, fossil evidence is sparse and we know virtually nothing about the ancestral history of this group. The taxa at the species level have been just as difficult to determine because of the simple morphology and the relative lack of characters. ${ }^{2}$

A new understanding of the taxonomy of this group has allowed the recognition of more species in Alberta and Saskatchewan; however, the numbers recorded for Manitoba have remained low. ${ }^{4,5}$ Scoggan, who wrote the classic "Flora of Manitoba" in 1957, recorded four Manitoba species all belonging to a single genus, i.e. common moonwort (Botrychium lunaria), daisy-leaf moonwort (B. matricariifolium), leathery grapefern (B. multifidum), and rattlesnake fern (B. virginianum). ${ }^{6}$ Since 1957 , other species have been added to this list as they were found, but there has not been a systematic examination of specimens from Manitoba. ${ }^{7.8}$

Ophioglossid ferns have no direct economic value; ${ }^{1}$ however, knowledge of their abundance and distribution would be as critical a contribution to our understanding of regional biodiversity and conservation needs as it is for any group of organisms. The goal of this study was to determine the taxa occurring in Manitoba, their distributions and relative abundances. To achieve this, it was necessary to study specimens collected within the province and from these records to make an annotated checklist and distribution maps for the taxa. Photographs and an identification key were also considered to be valuable.

\section{Materials and Methods}

Specimens of ophioglossid ferns were examined during 2009 and 2010 at the herbaria of The Manitoba Museum (MMMN), University of Manitoba (WIN), and the University of Winnipeg (UWPG). In addition, since 2005 I have prepared a temporary personal research collection 
as a result of searching for ferns and lycophytes throughout the province.

Each herbarium specimen was examined, compared with current species descriptions and annotated if necessary. 2,4,9 I followed the nomenclature and taxonomy that recognizes four local genera within the Ophioglossaceae, i.e. Ophioglossum, Botrychium, Botrypus, and Sceptridium.4,10 These genera were separated from each other because of consistently different features (see figures). The moonworts, Botrychium spp., have shoots consisting of two parts, a sporophore and a trophophore, no matter their size or age, whereas in the rattlesnake ferns (Botrypus virginiana) and grapeferns (Sceptridium spp.), the smaller plants do not produce fertile parts. The most obvious difference between rattlesnake ferns and grapeferns is that the trophophore of the former is attached well above ground, whereas that of the grapeferns is attached at or below ground level. Some texts have included Botrypus and Sceptridium as subgenera of a wider genus Botrychium. 9,11 An annotated species list was developed from these herbarium records (see below).

The collection location for each specimen was converted to Universal Transverse Mercator (UTM) coordinates wherever the information on the herbarium label was sufficiently precise. Collection locations were plotted on maps showing grids of 10 $\times 10 \mathrm{~km}$ and also $50 \times 50 \mathrm{~km}$ squares using the UTM system based on North American Datum 1983 (NAD 83). The distribution maps using $50 \times 50 \mathrm{~km}$ squares are shown below. Specimens that could not be placed within a $50 \times 50 \mathrm{~km}$ square due to unclear or imprecise locations were not included in the distribution maps.

\section{Results and Discussion}

Two hundred and twenty-two specimens of ophioglossid ferns were examined in total. These consisted of ten species (Table
1), but by far the most numerous were specimens of rattlesnake fern. All members of the genus Botrychium, the moonworts, are small and inconspicuous; it is likely that actual differences in the numbers of specimens reflect real differences in their specific abundances. This table also includes the numbers of squares both at the $10 \mathrm{~km}$ and $50 \mathrm{~km}$ levels, from which specimens of a particular species had been collected. These statistics provide an idea of the distribution, i.e., whether the species is widespread or has a relatively restricted range.

An exciting outcome of this study is that several taxa, including spatulate moonwort (Botrychium spathulatum) and least moonwort ( $B$. simplex), were recorded for the first time in Manitoba. The first of these species had been collected in the province before the taxon was officially recognized as being different from the common and Mingan moonworts. Blunt-lobed grapefern (S. oneidense) and prairie moonwort ( $B$. campestre) had been reported recently but were essentially new finds for the province. ${ }^{12,13}$ Species that were recorded for the second time only include: northern adder's-tongue (O. pusillum), daisy-leaf moonwort (B. matricariifolium), and spatulate moonwort (B. spathulatum). ${ }^{12,13}$

I was unable to locate specimens of pale moonwort (B. pallidum), which had been observed in the Otterburne area in southcentral Manitoba. ${ }^{8,14}$ It was not possible to confirm that this species occurs in the province in the absence of specimens and should remain as "of hypothetical occurrence" for the present.

The criteria that I found useful in identification were: shape of the trophophore and its pinnae, attachment point of the trophophore to the sporophore, degree of branching of the sporophore, habitat, phenology of spore production, and distribution. 
Table 1. Numbers of specimens of ophioglossid ferns in Manitoba herbaria (MMMN, UWPG, WIN, and author's collection), numbers of UTM squares in which the specimens were collected out of 6068 squares $(10 \times 10 \mathrm{~km})$ and out of 323 squares $(50 \times 50 \mathrm{~km})$, and rankings according to NatureServe Canada. ${ }^{15}$ NatureServe Conservation Status Ranks are as follows: $\mathrm{G}=\mathrm{Global}, \mathrm{S}=$ Subnational (i.e. province of Manitoba), 1=Very rare, 2=Rare, 3=Uncommon, 4=Abundant with possible unknown threats, 5=Abundant and secure, SNR=Species not ranked

\begin{tabular}{|l|c|c|c|c|}
\hline Common Name & $\begin{array}{c}\text { Herbarium } \\
\text { specimens }\end{array}$ & $\begin{array}{c}10 \times 10 \mathrm{~km} \\
\text { UTM squares } \\
\text { occupied }\end{array}$ & $\begin{array}{c}50 \times 50 \mathrm{~km} \\
\text { UTM squares } \\
\text { occupied }\end{array}$ & $\begin{array}{c}\text { Conservation } \\
\text { Status Ranks }\end{array}$ \\
\hline Rattlesnake fern & 149 & 98 & 52 & G5, S5 \\
\hline $\begin{array}{l}\text { Common } \\
\text { moonwort }\end{array}$ & 30 & 16 & 14 & G5, S4 \\
\hline $\begin{array}{l}\text { Leathery } \\
\text { grapefern }\end{array}$ & 17 & 14 & 13 & G5, S3 \\
\hline $\begin{array}{l}\text { Mingan } \\
\text { moonwort }\end{array}$ & 15 & 10 & 9 & G4, S1S2 \\
\hline $\begin{array}{l}\text { Northern } \\
\text { adder's-tongue }\end{array}$ & 3 & 2 & 2 & G5, S1 \\
\hline $\begin{array}{l}\text { Daisy-leaf } \\
\text { moonwort }\end{array}$ & 2 & 2 & 2 & G3G4, S1 \\
\hline $\begin{array}{l}\text { Spatulate } \\
\text { moonwort }\end{array}$ & 2 & 1 & 1 & G5, S1 \\
\hline $\begin{array}{l}\text { Prairie } \\
\text { moonwort }\end{array}$ & 2 & 1 & 1 & G5, SNR \\
\hline Least moonwort & 1 & 0 & 0 & G3, S1 \\
\hline $\begin{array}{l}\text { Blunt-lobed } \\
\text { grapefern }\end{array}$ & 1 & & 1 & \\
\hline Pale moonwort & 0 & 1 & & \\
\hline
\end{tabular}

It is clear that ophioglossid ferns are rare in Manitoba, with the notable exception of rattlesnake fern, which is both widespread and tolerably common. The remaining species are considered scarce at the provincial level based on criteria used by NatureServe Canada, as is shown by the Conservation Status Ranks given in Table 1. ${ }^{15}$

The question of whether to collect specimens of rare ophioglossids can and should be considered. On one hand, specimens are essential for verification, especially for a group of morphologically similar taxa which may continue to undergo taxonomic revision. On the other hand, it would be difficult to justify putting populations at risk by collecting individuals. Fortunately, the removal of the leaf after spores have been dispersed and the above-ground plant parts have started to senesce would seem to have little more effect than the removal of fall leaves from a deciduous shrub or tree, as long as the underground stem does not get damaged in the process. Any specimens collected should be donated to a herbarium along with the collection date, location, and habitat information to ensure their long-term care, storage, and research availability. 


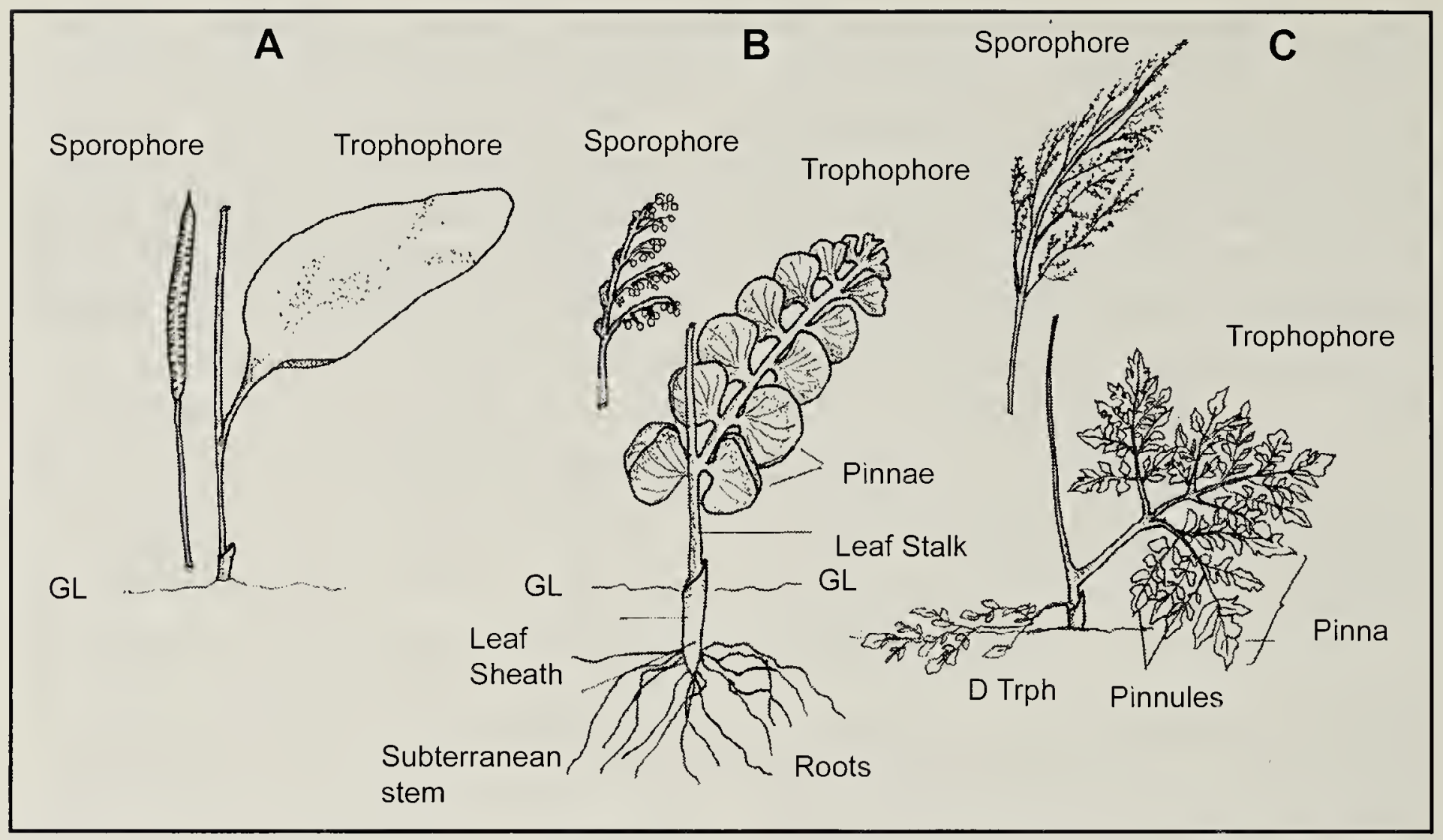

Figure 1. Terminology and morphology of ophioglossid ferns. (A) Northern adder's tongue with simple (= undivided) trophophore (leaf blade) with entire (= untoothed) margin. Its sporophore (fertile portion) is also simple (lacking branches), and its sporangia are embedded in its matrix. (B) Common moonwort with its pinnate compound leaf with paired, fan-shaped pinnae (leaflets). Its sporophore is branched and supports clusters of spherical sporangia. (C) Leathery grapefern with its deltoid (triangular) trophophore which is divided into pinnae and these divided again into pinnules (sub-leaflets) which are in turn divided a third time, i.e. the trophophore is thrice-compound. In this case, the sporophore is much branched and supports large clusters of sporangia which resemble bunches of grapes. Other terms: $G L=$ ground level, $d$ Trph=dead overwintering trophophore. Note that the three drawings are not drawn to the same scale.

\section{Key to genera and species of} ophioglossid ferns found in Manitoba

See Fig. 1. for illustrations of terms and morphology of ophioglossid ferns.

1a. Trophophore (sterile leaf section) single, simple with entire margins; sporangia sessile and embedded in a spike-like sporophore (fertile leaf portion)...... Ophioglossum pusillum

1b. Trophophores 1-4, compound; sporangia arranged on branched sporophores

2.

2a. All stems are fertile; fronds oncedivided or twice-divided, deciduous Botrychium (go to 5)

2b. Some stems without sporophores; fronds 2-4 compound, evergreen or deciduous 3a. Fronds deciduous; blade attached to stalk near middle

Botrypus virginianus

3b. Fronds evergreen; blade attached at ground level.

Sceptridium (go to 4)

4a. Terminal pinna (leaflet) similar in size to lateral pinnae, divided to near their tips

Sceptridium multifidum

4b. Terminal pinna of trophophores larger than laterals; not divided near their tips .... Sceptridium oneidense

5a. Distance between $1^{\text {st }}$ and $2^{\text {nd }}$ pairs of pinnae greater than between $2^{\text {nd }}$ and $3^{\text {rd }}$ pairs, $1^{\text {st }}$ pair of pinnae often divided into leaflets, terminal pinna broad.............. Botrychium simplex 
5b. Distance between $1^{\text {st }}$ and $2^{\text {nd }}$ pairs of pinnae hardly or not greater than between $2^{\text {nd }}$ and $3^{\text {rd }}$ pinnae......... 6 .

6a. Pinnae deeply segmented, with midrib (central vein) and lateral veins

Botrychium matricariifolium

6b. Pinnae entire, toothed or coarsely dentate but not deeply segmented, with fan-like veins and no midrib....7.

7a. Basal pinnae wide $\left(>120^{\circ}\right)$ and fanor kidney-shaped; pinnae usually overlapping ...... Botrychium lunaria

7b. Basal pinnae narrowly fan-shaped $\left(<90^{\circ}\right)$, or not fan-shaped; pinnae not usually overlapping 8.

8a. Trophophores folded lengthways with up to 5 pairs of pinnae ....... 9 .

8b. Trophophores not folded lengthways and up to 10 pairs of pinnae..... 10 .

9a. Pinnae very fleshy, basal pinnae linear with wide bases and symmetrical lobes, plant pale yellowish-green

Botrychium campestre

9b. Pinnae not fleshy, basal pinnae more or less fan-shaped with asymmetric lobes, plant whitish in colour

..Botrychium pallidum

10a. Trophophore narrow and oblong, pinnae shallowly lobed; lower branches of sporophore oncedivided .... Botrychium minganense

10b. Trophophore narrow and triangular, pinnae entire to coarsely toothed; lower branches of sporophore at least twice-divded

Botrychium spathulatum

\section{Annotated checklist of ophioglossid ferns found in Manitoba}

Photographs and distribution maps are shown in Figs. 2-6. Note: certain species of ophioglossid ferns occur in Saskatchewan or Alberta that have not been reported for Manitoba.
Prairie moonwort, Botrychium campestre W. H. Wagner \& Farrar

A single plant was discovered along a gravelly trail edge in Bird's Hill Provincial Park, S Manitoba by R. Staniforth in May 2005 and then reappeared during the following three springs, but not seen afterwards. ${ }^{12,13}$ Aerial parts appeared in late May or early June and had senesced by late June and early July. This is a species of prairies and dry places in the northern Great Plains with isolated populations around the Great Lakes and elsewhere in North America. ${ }^{9}$ It has been reported from Alberta and Saskatchewan. ${ }^{4,5}$ Prairie moonwort was originally described in $1981 .{ }^{9}$

\section{Common moonwort, Botrychium lunaria} (Linnaeus) Swartz

This moonwort is found throughout the northern half of the province but is scarce, except along the Hudson Bay coastline, where it is locally abundant on damp, exposed substrates, such as old sand and gravel pits. ${ }^{16}$ Double trophophores, triple sporophores, and fertile pinnae have been recorded among plants from the Churchill area. ${ }^{17,18}$ Sporangia ripen from mid-July to early September. Specimens from southern Manitoba are now considered to belong to other species. The most northerly Manitoba collection was from Seal River and the most southerly specimen from Playgreen Lake near the north end of Lake Winnipeg. It is widespread in northern and western North America, as well as in many other parts of the world. ${ }^{9}$ It occurs in both Alberta and Saskatchewan. ${ }^{4,5}$ This taxon was originally described in $1801 .{ }^{9}$

Daisy-leaf moonwort, Botrychium matricariifolium (Döll) A. Braun ex W.D.J. Koch

Only two specimens have been collected from the province, both from boreal granite 
outcroppings in central Manitoba. $\mathrm{H}$. Scoggan collected immature specimens from Norway House on 24 June $1948 .{ }^{6}$ The second Manitoba specimen with ripe, dehisced sporangia was found by $R$. Staniforth in late July 2007 in Wekusko Provincial Park. ${ }^{12,13}$ This species was first described in 1847 and is found in boreal regions across North America and Europe. ${ }^{9}$ It occurs in both Alberta and Saskatchewan. ${ }^{4,5}$

Mingan moonwort, Botrychium minganense Victorin

In Manitoba, the Mingan moonwort is of widespread but rare occurrence in forest clearings or in mixed forests. ${ }^{6}$ In Manitoba, sporangia ripen from mid-July to late August. The most northern specimens were collected from Goose Creek, near Churchill, and the most southern specimen was from Elm Point on Whitemouth Lake, SE Manitoba. This species is found across the northern and western regions of North America. ${ }^{17}$ It is found in both Alberta and Saskatchewan. ${ }^{4,5}$ Mingan moonwort was first described as a new species in $1927 .^{9}$

Pale moonwort, Botrychium pallidum W.H. Wagner

This species was included in a provincial plant list on the basis of a report from Otterburne, southern Manitoba. ${ }^{8,14}$ No voucher specimen has been seen and therefore its occurrence in Manitoba requires verification. It is a species of the Great Lakes region with disjunct populations elsewhere. ${ }^{9}$ This species has also been reported from Alberta, but not from Saskatchewan. ${ }^{4,5}$ This taxon was first described as a valid species in $1990 .^{9}$

Least moonwort, Botrychium simplex $\mathrm{E}$. Hitchcock

A single specimen is the only record for Manitoba. ${ }^{13}$ It was collected on 13 June 1994 by B. Ford, J. Starr, and E. and D. Punter from a sandy road convergence in a jack pine forest, near Badger, SE Manitoba. In common with the prairie and daisy-leaf moonworts, this is an "early-season" species; the spores of the Badger specimen were already ripening in mid-June. The least moonwort is found in both western and eastern North America, as well as in Europe. ${ }^{9}$ The Badger specimen is NW of its known eastern range which extends into northern Minnesota and NW Ontario. ${ }^{19}$ The species has also been reported from Alberta and Saskatchewan., ${ }^{4,5}$ The species was first described in $1823 .^{9}$

Spatulate moonwort, Botrychium spathulatum W.H. Wagner

A plant from Riding Mountain National Park collected in 1940 by C. Lowe was the first collection of this species from Manitoba. A second colony of about 2000 plants was discovered on a mud airstrip at Lake Waskaiowaka, north of Split Lake on 9 July 2010 by $R$. Staniforth. ${ }^{13}$ The plants were almost mature, and it is likely that sporangia would have been ripe by the end of July. This species occurs as several widely scattered populations in northern North America. ${ }^{9}$ This species has also been reported from Alberta, but not from Saskatchewan. ${ }^{4,5}$ The spatulate moonwort was not recognized as a distinct species until $1990 .^{9}$

Rattlesnake fern, Botrypus virginianus (Linnaeus) Holub, synonym: Botrychium virginiana (Linnaeus) Swartz

This is the most widespread and common member of this group of ferns in Manitoba. It is found in clearings and on disturbed soils in deciduous, mixed, and coniferous forests throughout most of the province except the far north. The most northern specimen had been collected from Lake Waskaiowaka, north of Split Lake. In Manitoba, the plants appear in June, and aerial parts are senescent by mid-September. The species was originally described in 1801, and is widespread 

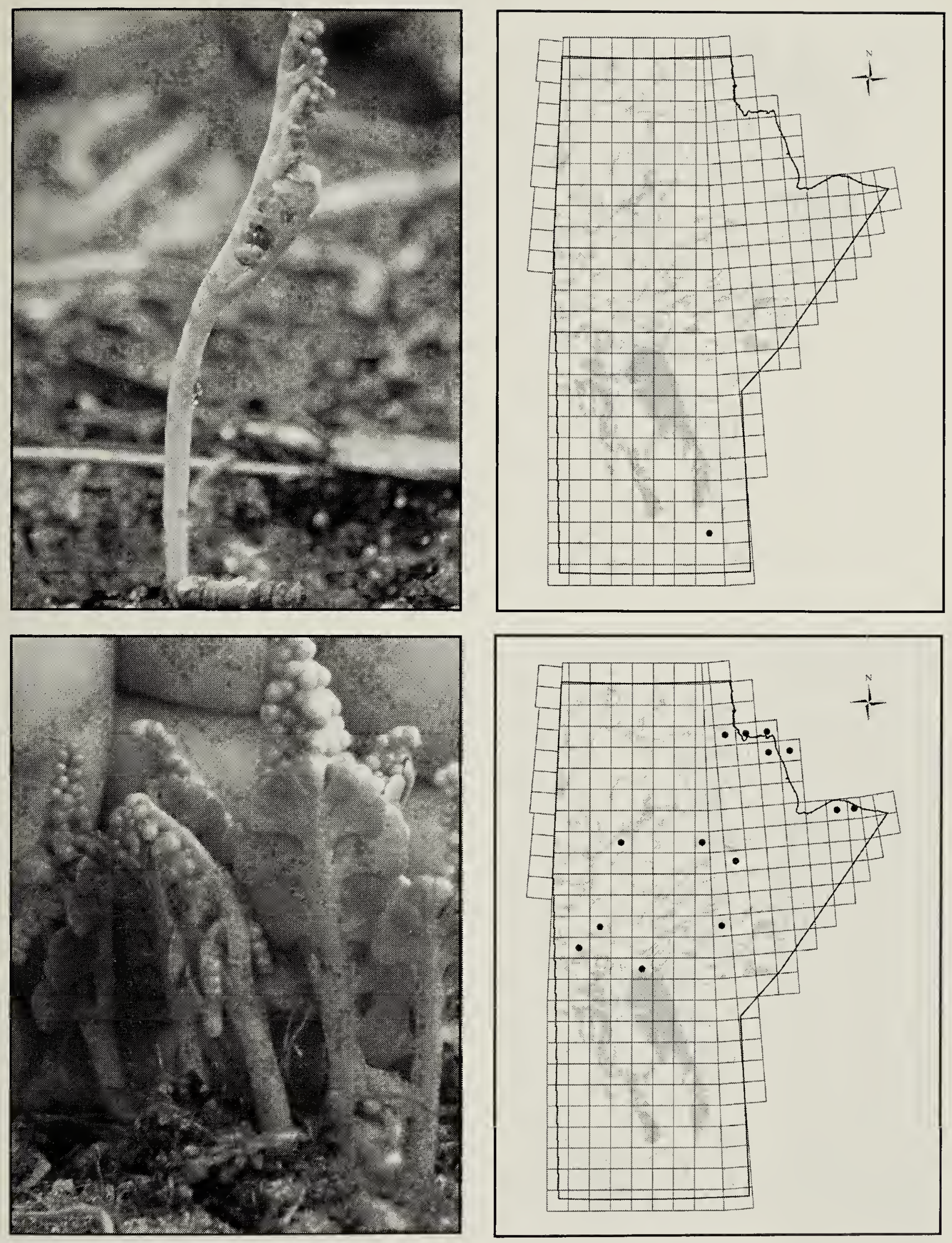

Figure 2. Upper photograph and map: prairie moonwort, Botrychium campestre, Bird's Hill Provincial Park. Lower photograph and map: common moonworts, Botrychium lunaria, Churchill. All photographs in Figs. 2-6 were taken by Richard Staniforth, and the maps were made by Colin Murray. 

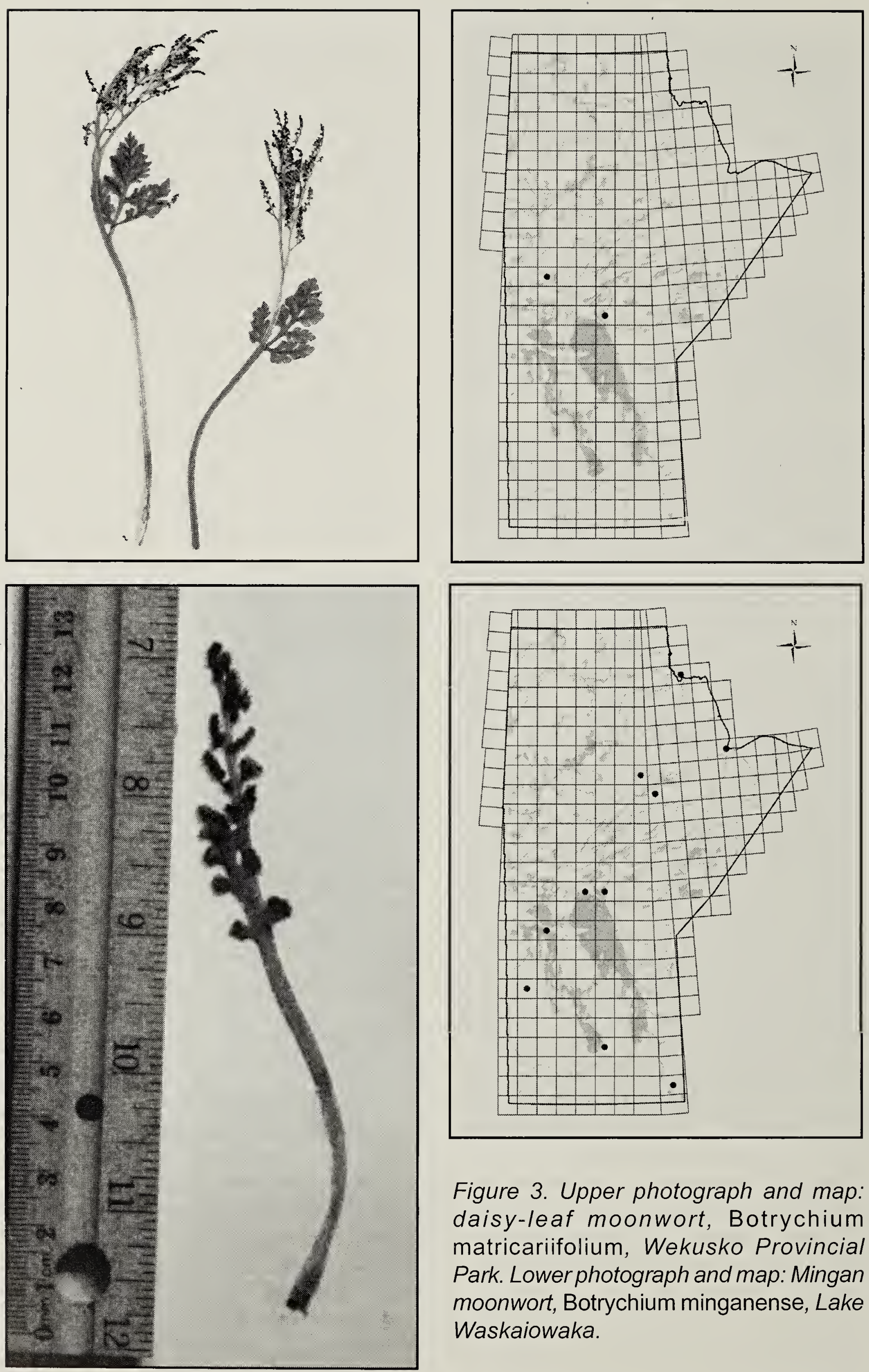

Figure 3. Upper photograph and map: daisy-leaf moonwort, Botrychium matricariifolium, Wekusko Provincial Park. Lower photograph and map: Mingan moonwort, Botrychium minganense, Lake Waskaiowaka. 

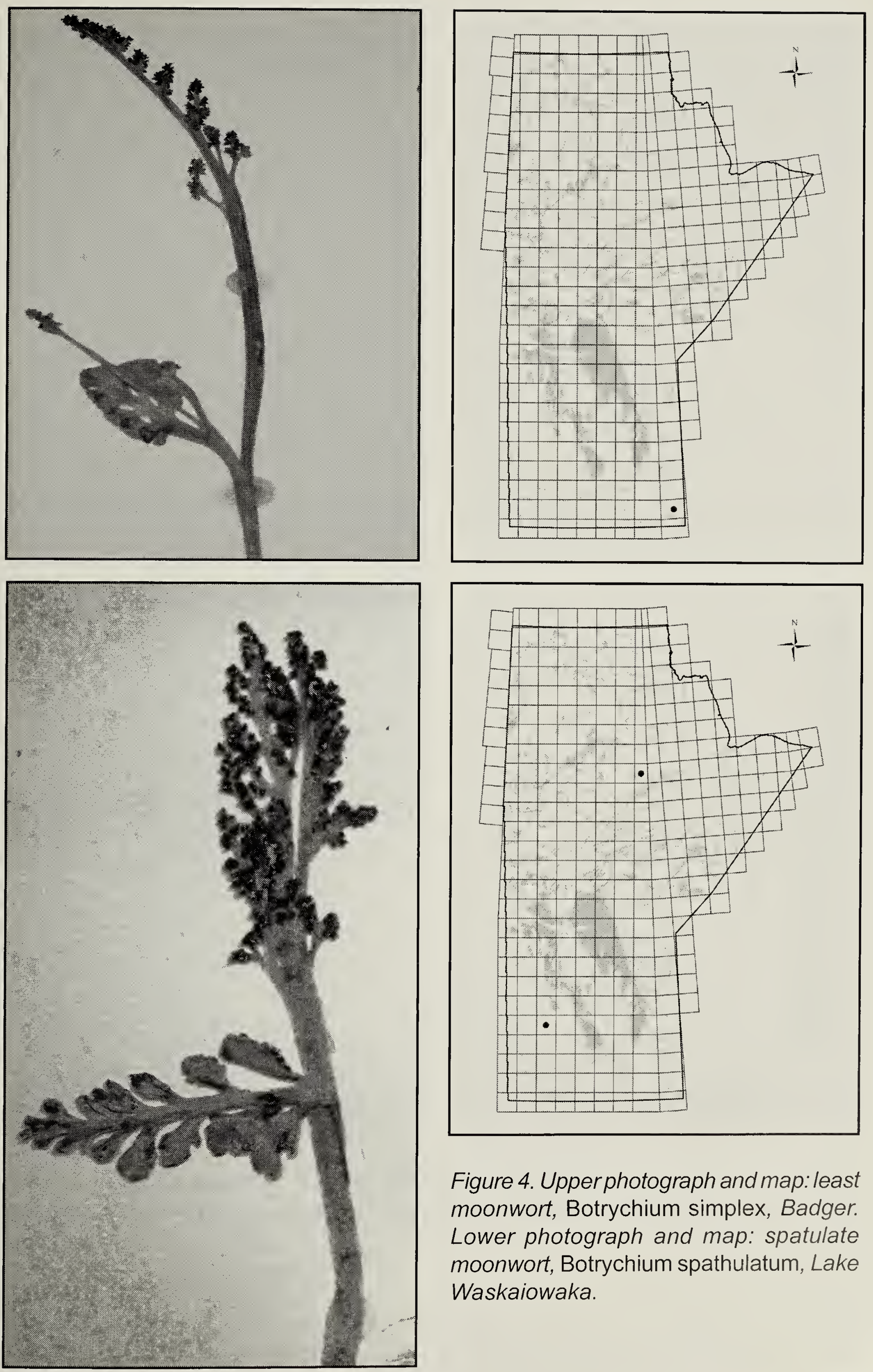

Figure 4. Upperphotograph and map: least moonwort, Botrychium simplex, Badger. Lower photograph and map: spatulate moonwort, Botrychium spathulatum, Lake Waskaiowaka. 

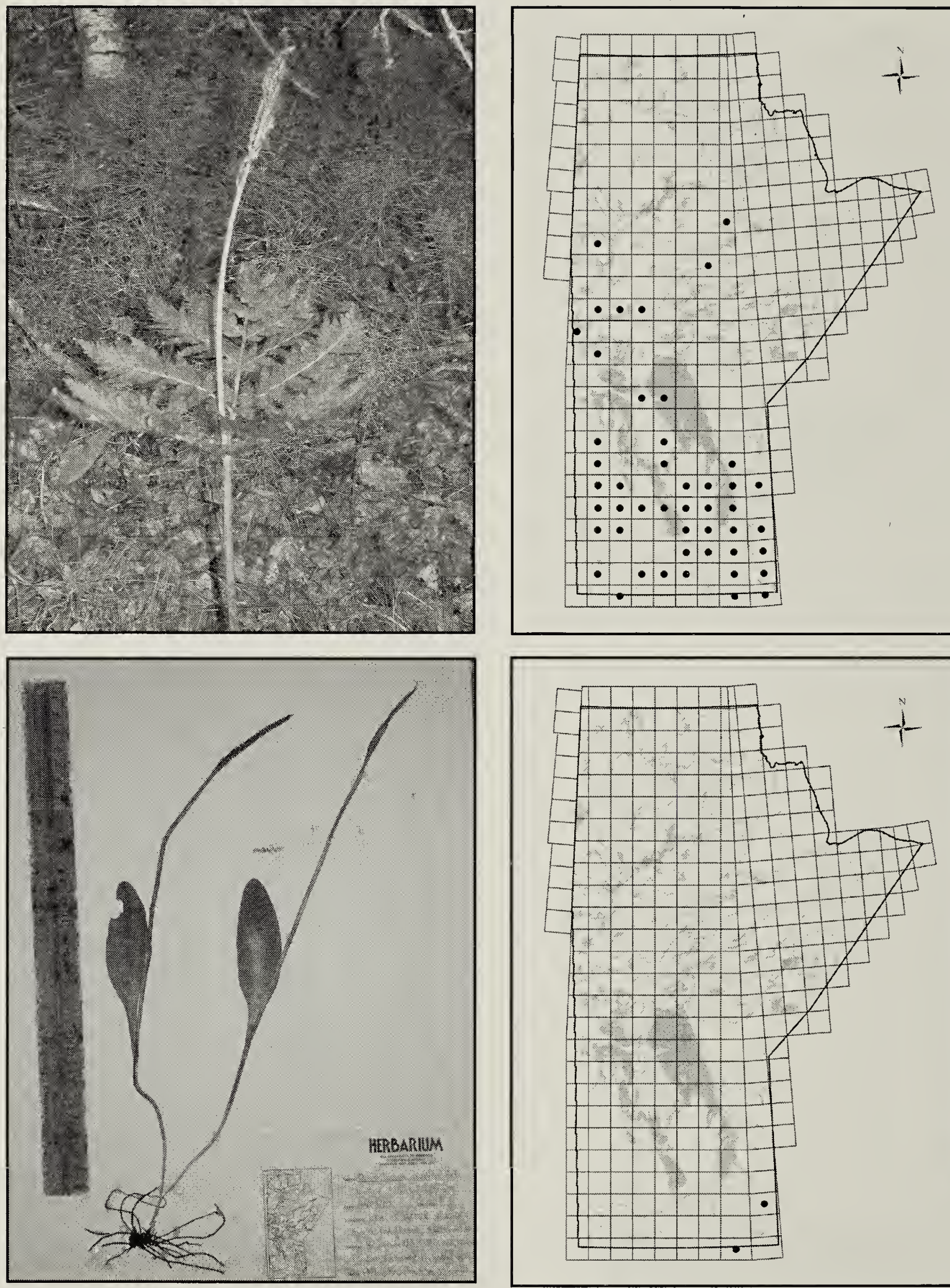

Figure 5. Upper photograph and map: rattlesnake fern, Botrypus virginiana, Hecla Provincial Park. Lower photograph and map: northern adder's-tongue, Ophioglossum pusillum, Rennie. 

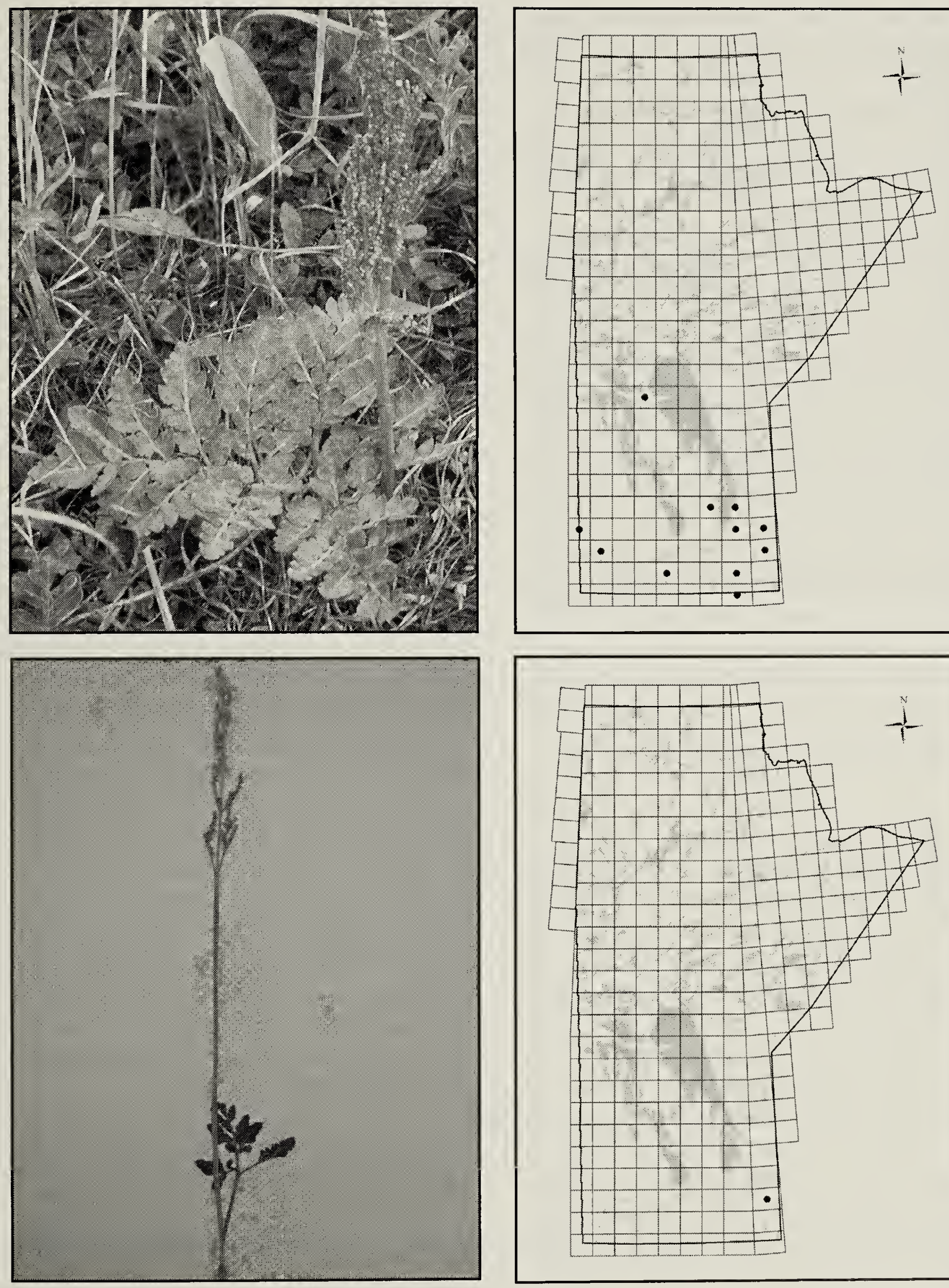

Figure 6. Upper photograph and map: leathery grapefern, Sceptridium multifidum, Libau. Lower photograph and map: blunt-lobed grapefern, Sceptridium oneidense, Star Lake. 
throughout North America and on other continents, except for arid and arctic regions. ${ }^{9}$ This species is also common in both Alberta and Saskatchewan. ${ }^{4,5}$

\section{Northern adder's-tongue, Ophioglossum} pusillum Rafinesque

An extensive, well-populated colony was discovered in 1996 in a wet swale near Vita, southern Manitoba, by L. Reeves..$^{20} \mathrm{~A}$ second colony of about 200 individuals was found in a ditch near Rennie, SE Manitoba, on 9 September 2008 by R. Staniforth. ${ }^{13}$ Aerial shoots do not appear until midJuly, and sporangia ripen in September. ${ }^{20}$ Populations of this species occur in both eastern and western North America ${ }^{9}$, but it has not yet been reported from either Alberta or Saskatchewan. ${ }^{4,5}$ The Manitoba populations have extended the known range of the eastern populations in a NW direction from NW Ontario and northern Minnesota. Northern adder's-tongue was described for the first time in $1814 .^{9}$

\section{Leathery grapefern, Sceptridium} multifidum (S.G. Gmelin) Nishida ex Tagawa, synonym: Botrychium multifidum (S.G. Gmelin) Ruprecht

The leathery grapefern is a rare but widespread species in southern and central Manitoba. In Manitoba, this species is usually associated with jack pinebearberry forests on sandy substrates. The most northerly specimen seen was from Grand Rapids. In Manitoba, the sporangia ripen in late August and September, and the foliage remains green over winter and senesces during the following spring. The species is found across northern North America and northern Eurasia. ${ }^{9}$ This species has also been reported from Alberta and Saskatchewan. ${ }^{4,5}$ Leathery grapefern was described as a new species in $1859 .{ }^{9}$

Blunt-lobed grapefern, Sceptridium oneidense (Gilbert) Holub, synonym: Botrychium oneidense (Gilbert) House
A single plant was recovered from ditch excavations among willows and alders, near Star Lake, Whiteshell Provincial Park, SE Manitoba on 25 September 2001 by R. Staniforth, K. Jones, and R. Cormack. ${ }^{12,13}$ This plant was mature and bore ripe spores when collected. This species is found across eastern North America westward to Minnesota. ${ }^{9}$ It has not yet been reported from either Alberta or Saskatchewan. ${ }^{4,5}$ The Star Lake plant is a NW extension of its known range. This taxon was first recognized in $1905 .^{9}$

\section{Acknowledgements}

I am very grateful to Diana Bizecki Robson and Janis Klapecki at The Manitoba Museum, and to Bruce Ford and Elizabeth Punter at the University of Manitoba for allowing me to study their Manitoba fern collections. I am grateful to the anonymous reviewer whose thoughtful suggestions greatly improved the manuscript. A large "thank you" also goes to Colin Murray for his patience and expertise in converting a mass of GPS coordinates into elegant distribution maps. The project would have included serious errors had it not been for the willingness of Don Farrar and Patrick Williston to share their knowledge and to make suggestions for specimens that had given me difficulties. I also thank Melissa Hoffer and Liza McClintock for their undergraduate studies on Botrychium spp. in Manitoba. ${ }^{21,22}$

1. Judd WS, Campbell CS, Kellogg EA, Stevens PF (2002) Plant Systematics. A Phylogenetic Approach. Sinauer Associates Incorporated, Sunderland, MA.

2. Farrar DR (2006) Systematics of moonworts Botrychium subgenus Botrychium. Department of Ecology, Evolution and Organismal Biology, lowa State University, Ames, IA.

3. Pryer KM, Smith AR, Skog JE (1995) Phylogenetic relationships of extant ferns based on evidence from morphology and $\mathrm{rbcl}$ sequences. American Fern Journal 85:203-282.

4. Williston $P$ (2001) The Botrychiaceae of Alberta. Alberta Natural Heritage Information Centre, Edmonton, $\mathrm{AB}$. 
5. Harms VL (2003) Checklist of the Vascular Plants of Saskatchewan and the Provincially and Nationally Rare Native Plants in Saskatchewan; including important Synonyms, Authorities, Common Names, and various Status Indicators. University Extension Press, University of Saskatchewan, Saskatoon, SK.

6. Scoggan HJ (1957) Flora of Manitoba. National Museum of Canada. Bulletin No. 140. Biological series No. 47. Department of Northern Affairs and National Resurces, Ottawa, ON.

7. Cody WJ, Britton DM (1989) Ferns and Fern Allies of Canada. Publication 1829/E. Research Branch, Agriculture Canada, Ottawa, ON.

8. Punter E (1995) Manitoba's Vascular Plants. Manitoba Conservation Data Centre, Winnipeg, MB.

9. Wagner WH Jr, Wagner FS (1993) Ophioglossaceae. In: Flora of North America. Volume 2: Pteridophytes and Gymnosperms. Oxford University Press Incorporated, New York, NY, p 85-109.

10. Kato M (1987) A phylogenetic classification of Ophioglossaceae. Gardens Bulletin (Singapore) 40:1-14.

11. Cobb B, Farnsworth E, Lowe C (2005) A Field Guide to the Ferns and their Related Families of Northeastern and Central United States. $2^{\text {nd }}$ edition. New England Wildflower Society. The Peterson Field Guide Series. Houghton Mifflin, New York, NY.

12. Staniforth RJ (2009) More exciting plant discoveries in Manitoba. Nature Manitoba News 1 (2):11.

13. Staniforth RJ (2011) Rattlesnakes, Adder'stongues and Moonwort Madness in Manitoba. Nature Manitoba News. (In press).
14. Löve D, Bernard JP (1959) Flora and vegetation of the Otterburne area, Manitoba, Canada. Svensk Botanisk Tidskrift 53:335-461.

15. NatureServe (2010) NatureServe Explorer: an online encyclopedia of life [web application]. Version 6.0. NatureServe, Arlington, VA. Available at http:// www.natureserve.org/explorer

16. Johnson KL (1987) Wildflowers of Churchill and the Hudson Bay Region. Manitoba Museum of Man and Nature, Winnipeg, MB.

17. Friesen P (2007) Moonworts in Manitoba: morphological variations of Botrychium lunaria from Churchill, MB. Report for the Department of Biology, University of Winnipeg, Winnipeg, MB.

18. Staniforth RJ, Friesen P (2011) Unusual morphology amongst common moonworts (Botrychium lunaria) from Churchill, Manitoba. Blue Jay 69(1):34-35.

19. Tryon RM Jr (1954) The Ferns and Fern Allies of Minnesota. University of Minnesota Press, Minneapolis, MN.

20. Reeves L (2004) Rare Plant of the Month. Northern Adder's-tongue (Ophioglossum pusillum). Native Orchid News 6 (2):1-4.

21. Hoffer M (2007) Manitoba's Ophioglossid Ferns. Report for the Department of Biology, University of Winnipeg, Winnipeg, MB.

22. McClintock $L$ (2002) A Study of the Family Ophioglossaceae in Manitoba. Report for the Department of Biology, University of Winnipeg, Winnipeg, MB.

Humankind has not woven the web of life.

We are but one thread within it.

Whatever we do to the web, we do to ourselves.

All things are bound together.

All things connect.

- Chief Seattle, 1854 